\title{
EVALUATION EFFECT OF APPLICATION METHODS OF DIFFERENT SOURCES OF HUMIC SUBSTANCES ON POTATOES PLANT GROWTH, PRODUCTIVITY AND QUALITY IN NEWLY RECLAIMED SANDY SOIL UNDER DIFFERENT LEVELS OF MINERAL FERTILIZERS
}

\author{
B.Y. EL Komy ${ }^{(1)}$, E.A. Abou Hussein ${ }^{(1)}$, Manal F. Tantawy ${ }^{(2)}$ \\ and Elham M.N. El Sayed ${ }^{(1)}$ \\ (1) Soil Sci. Dept., Fac. of Agric., Menoufia Univ., Egypt. \\ ${ }^{\text {(2) }}$ Soil, Water \& Environ. Res. Institute, Agric. Res. Center "ARC", Giza, Egypt.
}

Received: Aug. 22, 2021

Accepted: Sep. 6, 2021

\begin{abstract}
The present work was conducted to: evaluate the effect of application methods of CT, HA and FA individually or in combination without and with recommended mineral fertilizers doses (RMFD) (50 and $100 \%$ ), on potato growth and their yields. To achieve these objectives, a field experiment during winter seasons of 2019 was conducted at El Nagah Village, El-Tahrir Region, El Beheira Governorate, Egypt (Latitude $30^{\circ} .40^{\prime} \mathrm{N}$ - Longitude $30^{\circ} .33^{\prime} \mathrm{E}$ ) (represented newly reclaimed sandy soil). The layout of the experiment was a split- plot design, with the main plots arranged in a randomized complete blocks design with three replicates. Potatoes (Solanum tuberosum $L$ ) plants cultivar Spunta, as a tuber crop. Three application methods of the used organic amendments were applying. These methods were: soil application (through drip irrigation "Drip"), foliar spray "Spray" and the alternative between them "Spray/Drip". The application methods of "Spray/Drip" was carried out by applying half amount of each organic amendments applying as soil application and the other $50 \%$ was applied as foliar spray). This study including the treatments of control (without any applications of organic amendments treatment). The used CT was added at a rate of $200 \mathrm{~L} \mathrm{fed}^{-1}$. FA and $\mathrm{HA}$ were added at a rate of 6 and $10 \mathrm{Kg} \mathrm{fed}^{-1}$. respectively. The used mineral fertilizers (NPK) were applied at two rates (50 and $100 \%$ of recommended dose for the potato plants. After $\mathbf{4 0}$ and $\mathbf{6 5}$ days from sowing, dry matter yields (DMY) of the growing plants (shoots) and at harvesting, tuber yield per fed. "feddan $=4200 \mathrm{~m}^{2}$ "), as well as quality traits their elemental composition, mainly contents of nitrogen, phosphorus, potassium were determined.

The obtained results indicated that, DMY (shoots and tuber) of potato plants received the combined application of CT+ HA+ FA were the highest values under all application methods compared to their individual application, under both levels of mineral fertilization, at 40 and 65 days after sowing for shoots as well as at harvesting for tubers. The maximum values of $\mathrm{N}, \mathrm{P}$ and $\mathrm{K}$ contents of potato shoot at 40 and 65 days after sowing and in tubers were obtained from double application (Spraying/Drip) method treatments of the in-combination treatments of organic amendments under both levels of recommended mineral fertilization. Accordingly, the duple application "Spray/Drip" methods of organic amendments, considered a more beneficial application methods in the cultivation of potato plants (Spunta cultivar) in newly reclaimed sandy soils due to it resulted in a high tuber yield, quality and reducing the environmental pollution as a result from reducing the additions of the mineral fertilizer with the in combination organic amendments.
\end{abstract}

Key words: Compost tea, Humic, Fulvic acids, Drip irrigation, Foliar spray, Mineral fertilizers, Potato crop and Sandy soil 


\section{INTRODUCTION}

The world is currently facing the combined challenges of feeding a growing population whilst also protecting the environment and producing renewable sources of energy. Demand for food is expected to increase 2-5 fold by 2030 and food production is predicted to increase by $60 \%$ in the coming decades to meet these demands (Clair and Lynch, 2010).

The excessive use of mineral fertilizers in agriculture is an issue of concern. It causes high level of the pollutants in different plant parts, decrease soil fertility and pollution of groundwater (Hernandez et al., 2010). Organic fertilizers can be used to reduce the amount of toxic compounds (such as nitrate and others) produced by mineral fertilizers, improving the quality of vegetables produced as well as human health (Mahmoud et al., 2009).

New approaches to help promote sustainable intensification are therefore required. One potential solution to help in this transition is the use of plant biostimulants based on compost tea and humic substances. Compost tea (CTs) are instead obtained by a fermentation/oxidation process that determines new condition in the main physicochemical and microbiological characteristics of the end-products. The content of HSs and mineral nutrients increases into CTs during the fermentation/oxidation process with respect to the compost from which it is derived (Ingham, 2005). Such soluble organic molecules seemed to have beneficial effects on the plant metabolic processes thanks to their particular structure (Zandonadi et al., 2019). Likely organic compounds, also bacteria, fungi, and yeasts have a decisive impact in the CTs ability to suppress diseases and/or promote plant growth (Khaled and Fawy,
2011 and Morard et al., 2011). Several findings about the plant stimulant effects by CTs and their derivatives application were reported in literature of Dionne et al. (2012). In particular, authors described many effects on nutrient uptake and $\mathrm{N}$ assimilation, hormone-like activity, photosynthetic efficiency, rootassociated microorganisms for plant nutrition and nutrient uptake, growth parameters, and phytosanitary condition (Palumbo et al., 2018).

Humic substances (HS) concentration required by the effective action on plant metabolism and growth when applied via soil is greater than those rates required when HSs are supplied via foliar spray (Anjun et al. 2011). Therefore, considering that most of the studies investigate soil applications of HS (Calvo et al., 2014), studies with foliar application of HS are important to set adequate concentrations of different molecules regarding this specific application mode. Vegetative growth yield and tuber quality as well as the tuber nutritive value of potato significantly increased with humic acid level increase where no significant differences were noticed between 1 and 2 $\mathrm{kg} \mathrm{fed}^{-1}$. Humic acid application led to positive changes in vegetative growth, leaf area index due to increase in root growth and nutrients availability (Hanafy et al., 2018). Tuber yield increased by $16.47 \%$ after addition of humic substances compared to the recommended rate solely. Soil application of humic acid significantly increased plant growth, photosynthetic pigments, total and marketable yield and tuber root quality. Humic acid at $0,10,20$ and $30 \mathrm{ml} \mathrm{L}^{-1}$ of irrigation water enhanced potato growth parameters, yield and tuber physical and chemical properties. The highest dose of the HSs resulted in highest plant vigor increase, the heaviest tuber yield and the best tuber properties 
(Selim et al., 2012). Potato crops is the world's fourth largest food crop where it plays an important role as a staple food in the Mediterranean Basin countries. The crop occupied an overall area about 1 million hectares which produced 28 million tons of tubers (FAO, 2017). In Egypt, potato could be considered as one of the cash crops and its economic importance arises from the fact that large amount of this crop is exported yearly (Eleiwa et al., 2012).

The functions of HSs for the enhancement of plant growth widely differ depending on the application mode, plant stage, and its rate. Basically, there exist five application types of HSs in the field (Ekin, 2019). Several works report a comparative study of different application methods of HSs. Waqas et al. (2014) compared three application modes (foliar spray, soil application, and immersion) for horticultural crops. They concluded that foliar spray performed higher yield than soil application in tomato, maize, almond, and sugarcane (Da Silva et al., 2017). An ideal implementation would be combined applications rather than a single application method, which was demonstrated by Bettoni et al. (2016) with higher nutritional quality and yield of onion.

Great opportunities exist to increase potato yield and quality by improving nutrient management. Potato demands high level of soil nutrients due to relative poorly developed and shallow root system in relation to yield. Effective management of nutrients is critical for potato production, as tuber yield and tuber quality are directly impacted by quantity and timing of nutrient applications (Muleta and Aga, 2019).

The aim of this study which carried as field experiment was evaluating the application methods i.e foliar, soil application and both foliar/soil application of compost tea, humic and fulvic acids with 50 and $100 \%$ of recommended mineral fertilization on growth and productivity of potatoes (Solanum tuberosum L.) in newly reclaimed sandy soil. As well as quality traits of tuber and their content of nitrogen, phosphorus, potassium in potato plants, were determined.

\section{MATERIALS AND METHODS}

\section{A. Materials \\ 1. Soil location and soil sampling}

Before planting, surface soil samples $(0-20 \mathrm{~cm})$ were taken from five different sites at private farm at EI Nagah Village, El-Tahrir Region (Latitude 30‥40'NLongitude $\left.\quad 30^{\circ} .33^{\prime} \mathrm{E}\right) \quad$ - Beheira Governorate, Egypt. These soil samples were air-dried, ground, good mixed and sieved through a $2 \mathrm{~mm}$ sieve. The fine and sieved soil (>2 $\mathrm{mm}$ ) was analyzed for some physical and chemical properties and also for its content of total and available macro- and micronutrients were determined according to Klute (1986), Cottenie et al. (1982) and Page et al. (1982). The obtained data are recorded in Table (1).

\section{Organic amendments}

In this study different three resources of organic materials i.e. compost tea "CT", fulvic and humic acids "FA" and "HA" were used as organic amendments. The used HA and FA were purchased from the Agriculture Commercial market and the compost tea was prepared in the laboratory. The three organic amendments were analyzed for some physical and chemical properties according to the methods by Page et al. (1982). The functional groups of humic and fulvic acids $(\mathrm{cmolc} / \mathrm{Kg})$ were determined as follows: Total acidity were determined using the procedure described by Dragunova (1958). Carboxyl groups were determined by calcium acetate method, as described by Kukharenko (1937). Total hydroxyl 
groups were estimated by acetylation methods as described by Brooks et al. (1958). Phenolic hydroxyl groups were assumed to be equal to the difference between total acidity and carboxyl groups (Kononove, 1966). The obtained data are recorded in Table (2).

\section{Aerated compost tea preparation}

Representative $10 \mathrm{Kg}$ commercial mature compost (prepared from cow manure $(70 \%)$ and agricultural wastes $(30 \%)$ has been extracted; at extraction ratio of $1: 10$ as described by Ingham (2005).

Table (1): Some physical and chemical properties and nutrient contents of the field experimental soil

\begin{tabular}{|c|c|c|}
\hline Properties & Unit & $\begin{array}{c}\text { Values (average of the composite } \\
\text { sample) }\end{array}$ \\
\hline Particle fraction: & $\%$ & $\begin{array}{c}77.2 \\
13.5 \\
9.3\end{array}$ \\
\hline Textural grade & & Sandy loam \\
\hline Field capacity & $\%$ & $19.6 \%$ \\
\hline Organic matter & $\%$ & 0.78 \\
\hline pH (1:2.5 soil/ water suspension) & & 7.8 \\
\hline E.C (1:5 soil:water extract "TSS") & $\mathrm{dSm}^{-1}$ & 1.14 \\
\hline $\begin{array}{r}\mathrm{Na}^{+} \\
\mathrm{K}^{+} \\
\mathrm{Ca}^{++} \\
\mathrm{Mg}^{++}\end{array}$ & \multirow{2}{*}{ 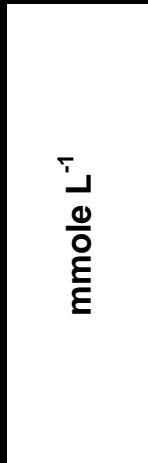 } & $\begin{array}{l}6.0 \\
0.4 \\
2.5 \\
2.5\end{array}$ \\
\hline Soluble anion: & & $\begin{array}{l}8.0 \\
0.9 \\
0.0 \\
2.5\end{array}$ \\
\hline Total $\mathrm{CaCO}_{3}$ & \multirow{4}{*}{$\mathrm{g} \mathrm{Kg}^{-1}$} & 36.0 \\
\hline Total N & & 1.5 \\
\hline Total P & & 1.4 \\
\hline Total K & & 7.0 \\
\hline Available macronutrient: & \multirow{3}{*}{$\mathrm{mg} \mathrm{kg}^{-1}$} & 28.40 \\
\hline 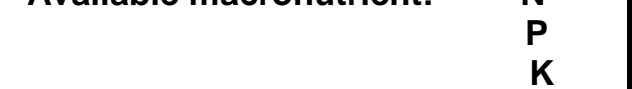 & & $\begin{array}{c}3.09 \\
75.22\end{array}$ \\
\hline \multirow[t]{3}{*}{ Available micronutrient: } & & 4.78 \\
\hline & & 6.76 \\
\hline & & 0.84 \\
\hline
\end{tabular}

\section{Mineral fertilizers}

The used mineral fertilizers in this study were: ammonium sulfate "( $\left(\mathrm{NH}_{4}\right)_{2} \mathrm{SO}_{4}, \quad 20.5 \% \mathrm{N"}$ and ammonium nitrate " $\mathrm{NH}_{4} \mathrm{NO}_{3} 33 \% \mathrm{~N}$ " as a source of nitrogen. Calcium superphosphate $" \mathrm{Ca}(\mathrm{H} 2 \mathrm{PO} 4)_{2}{ }^{\prime} \quad 15.5 \% \quad \mathrm{P}_{2} \mathrm{O}_{5} "$ and phosphoric acid (H3PO4), which characterized by: specific density of 1.54 $\mathrm{gm} \mathrm{cm}^{-3}$, purity percent of $85 \%$, and 41.4 $\%$ P $\left(95.22 \% \mathrm{P}_{2} \mathrm{O}_{5}\right)$, as a source of phosphorus. Potassium sulfate $" \mathrm{~K}_{2} \mathrm{SO}_{4}$, $48 \% \mathrm{~K}_{2} \mathrm{O}$ " as a source of potassium. 


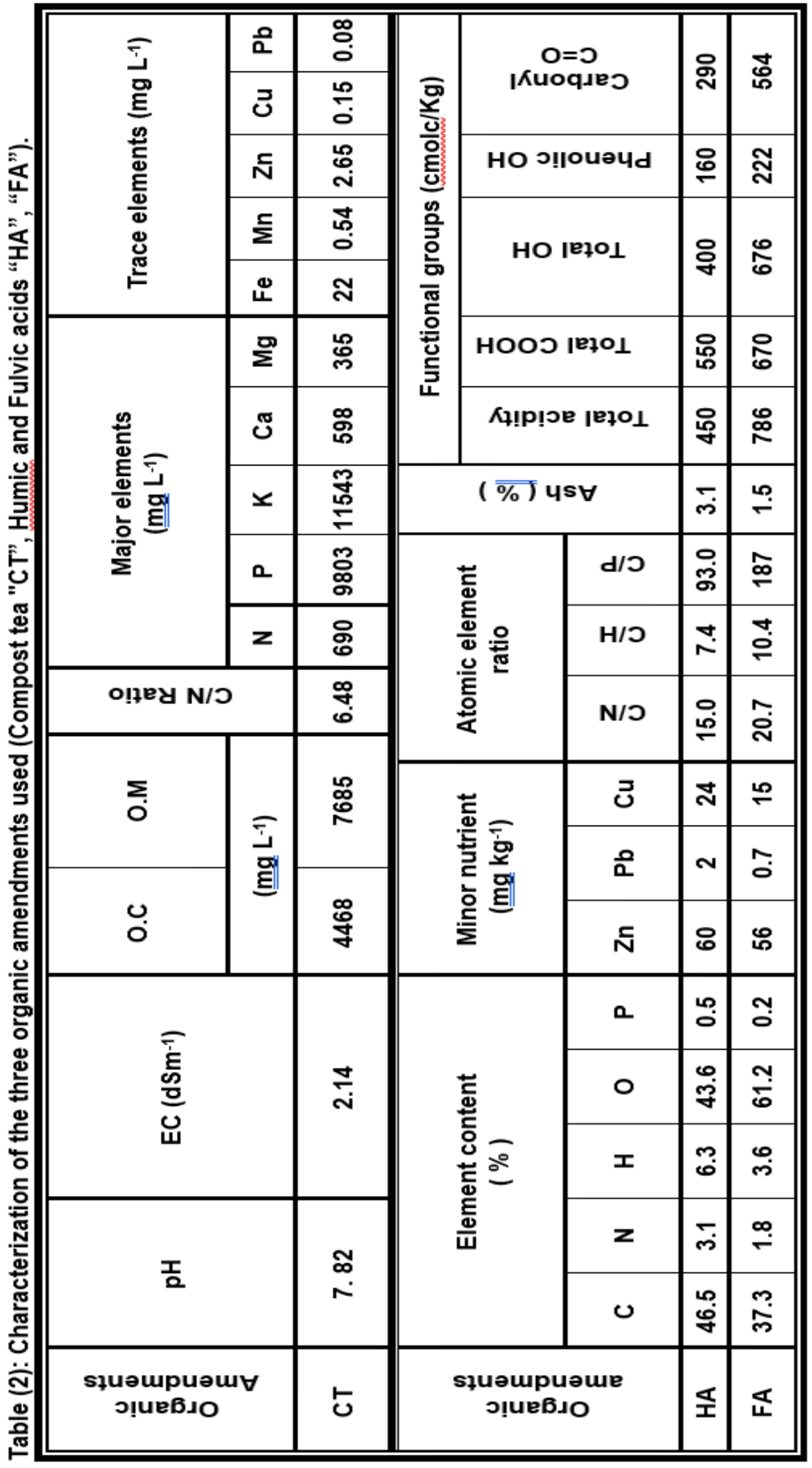




\section{B. The Experimental Treatments}

1-Main treatments: (application methods of organic fertilizers): Three application methods of the used organic amendments were applying. These methods were: soil application (through drip irrigation "Drip"), foliar spray "Spray" and the alternative between them "Spray/Drip". The last application methods "Spray/Drip", half amount of each organic amendments were applying as soil application and the other $50 \%$ were applied as foliar spray).

2- Sub-treatments (resources of organic amendments): Control (without any applications of organic fertilizers) and three organic amendments i.e. compost tea, fulvic acid, humic acid and combined application of $\mathrm{CT}+\mathrm{FA}+\mathrm{HA}$ were used in this study.

3- Sub-sub-treatments (mineral fertilizers): The used mineral fertilizers (NPK) were applied at two rates (50 and $100 \%$ of recommended dose for potato plants, according to Egyptian Ministry of Agriculture $\left(85 \mathrm{Kg} \mathrm{N} \mathrm{fed}^{-1}\right.$, $15 \mathrm{Kg} \mathrm{P}_{2} \mathrm{O}_{5}$ fed $^{-1}$ and $48 \mathrm{Kg} \mathrm{K}_{2} \mathrm{O}$ fed $^{-1}$ ).
4- Control (without organic amendments).

\section{Field Experiment}

A field experiment was conducted at EI Nagah Village, Tahrir regions, EL Beheira Governorate, Egypt (Latitude $30^{\circ} .40^{\prime} \mathrm{N}$ - Longitude $30^{\circ} .33^{\prime} \mathrm{E}$ ) (sandy loam soils represented newly reclaimed soil). The studied treatment was arranged with the experimental units in split/split plot design in three replicates where the area of each plot was $10.5 \mathrm{~m}^{2}(3.5 \times 3 \mathrm{~m})$.

Potatoes tuber (Spunta cultivar) was obtained from Horticulture Research Institute, ARC, Giza, Egypt. Before planting all experimental plots were fertilized by farmyard manure at application rate of $10 \mathrm{~m}^{3} \mathrm{fed}^{-1}$. At the same time the soil of each sub/sub plots was fertilized by ordinary super phosphate $\left(15.5 \% \mathrm{P}_{2} \mathrm{O}_{5}\right)$, at two rates of 25 and $50 \mathrm{~kg} \mathrm{fed}^{-1}$ (3.75 and $7.5 \mathrm{Kg} \mathrm{P}_{2} \mathrm{O}_{5}$ fed $^{-1}$ ) represent the 25 and $50 \%$ of $P$ recommended mineral fertilization dose, respectively. The planting date was at 5 October 2019. Potatoes tubers were planted at a rate of $1.250 \mathrm{Mg}^{-1} \mathrm{fed}^{-1}$ with a $60 \mathrm{~cm}$ between rows, whole tubers (50-60 g) were planted at a depth of $10 \mathrm{~cm}$ and field management was conducted. The used irrigation system was drip irrigation where irrigation water must be applied at moisture content at field capacity. The rate and date added of the three organic amendments in the three tested application methods (through drip irrigation system "Drip" or foliar spray "Spray" and both "Spraying/Drip"): Compost tea CT were added at a rate: of $200 \mathrm{~L} \mathrm{fed}^{-1}$. Both humic HA and fulvic acids "FA" were added separately at a rate of 10 and $6 \mathrm{Kg}^{\text {fed }}{ }^{-1}$, respectively. The combined application of: CT, HA and FA was applied at a rate of $100 \mathrm{~L}, 5$ and 3 $\mathrm{Kg} \mathrm{fed}{ }^{-1}$ respectively. All organic amendments were applied in three equal doses at 21,30 and 40 days after sowing.

As mentioned before that $50 \%$ of experimental plots were fertilized by $50 \%$ of recommended mineral fertilizers $(N, P$ and $\mathrm{K}$ ) recommended by Egyptian ministry of Agriculture for potatoes plants, while the other $50 \%$ of the plots were fertilized by $100 \%$ of the same fertilizers recommended dose. The normal cultural practices for potatoes crop, i.e. irrigation and pest control were followed according to recommendation of Egyptian Ministry of Agriculture.

After 40 and 65 days of sowing, three plants of each replicate representing the studied treatments i.e. 9 plants for each treatment were taken separately as a whole. The plants of each replicate were leached generally using tap water to remove the soil particles. After that, the harvested plants materials air dried and oven dried at $70{ }^{\circ} \mathrm{C}$ for $72 \mathrm{hrs}$. and weighed to obtain the dry matter yield of shoots. 
At harvest stag (110 days after sowing), the tubers of each replicate of the one treatment were taken to determine the yield $\left(\mathrm{Mg} \mathrm{fed}^{-1}\right)$. A portion of each plant sample was oven dried at $70{ }^{\circ} \mathrm{C}$ for $72 \mathrm{hrs}$., ground and kept in dried and clean glass bottles up to chemically analyzed to their content of $\mathrm{N}, \mathrm{P}$ and $\mathrm{K}$ (\%) which carried out according to Cottenie et al. (1982). Data of the present study were statistically analyzed using COSTATE Computer Software, according to Gomez and Gomez (1984). Significant differences among treatments means of the studied parameters data were determined at $P \leq 0.05$ by using LSD test.

\section{RESULTS AND DISCUSSION}

1. Dry matter yields (DMY) of potato shoots.

Data in Table (3) demonstrated that, all application methods applications of $\mathrm{CT}$, FA and HA individually or in-combination significantly augmented the dry matter yields (DMY) of potato shoots at 40 and 65 days after sowing (DAS), as compared to the untreated one (control treatment) under both levels of mineral fertilization "NPK" i.e. 50 and $100 \%$ of their recommended mineral fertilizers dose (RMFD). These data pointed out that, the application methods of organic amendments have a wide differences in DMY of potato shoots at 40 and 65 DAS, especially with the application method of spraying/drip under the mineral fertilization treatments. With the individual or the in-combination of organic amendments (CT, FA and HA) and mineral fertilizers, the obtained DMY of shoot potato plants received the $100 \%$ of the RMFD were significantly higher than those received the $50 \%$ of RMFD, under the different application methods at the two planting stages (40 and 65 DAS). DMY of plant shoots were 1.189 and 1.436 and 2.140 and $2.637 \mathrm{Mg} \mathrm{fed}^{-1}$ for the potato shoots received the fulvic acid by Spraying/Drip application methods under the two levels of mineral fertilization, at 40 and 65 DAS, respectively. Where the maximum values were 1.206 and 1.552 and 2.275 and 2.706 $\mathrm{Mg} \mathrm{fed}{ }^{-1}$, for the same all abovementioned treatments with combined application of CT, FA and HA. These results are in the same line with those obtained by Ibrahim (2019) and Bezuglova et al. (2019). These findings confirm with those carried out by Yaxin et al. (2019). It is worthy to mention that the compost tea (CT) contains many of microorganisms that able to IAA (Indole acetic acid) production, nitrogenase activity and solubilization $P$. The application of compost tea with humic substances (FA and HA) lead to an increase in production of hormones, stimulating plant growth; one proposed mechanism to explain the benefits of compost application (Arancon et al., 2008).

\section{Macronutriment (N, P, K) content \\ a. Nitrogen (N) content}

Data listed in Tables (4 to 9) showed that a significant increases in $\mathrm{N}, \mathrm{P}$ and $\mathrm{K}$ content of the potato shoot plants due to the application methods of CT, FA and HA individually or their in-combination with mineral fertilizers at the two levels compared to their controls. Data in Table 4 and 5 show that, nitrogen content (\%) and uptake $\left(\mathrm{Kg} \mathrm{fed}^{-1}\right)$ by shoots potato with all application methods treatment of individually or in combined application of CT, FA and HA and mineral fertilizers were significantly increased compared to the nitrogen content of control (without any organic amendments) under the two levels of RMFD. The maximum values of $\mathrm{N}$ content of potato shoot at 40 and 65 DAS were obtained from mixed application (Spraying/Drip) method treatments of the combination application of compost tea, fulvic acid and humic acid under $100 \%$ of RMFD. These correspondent values at $\mathbf{4 0}$ days was $3.63 \%$ which equal to $56.28 \mathrm{Kg} \mathrm{fed}^{-1}$, whereas at 65 DAS was $4.53 \%$ which equal to $122.67 \mathrm{Kg} \mathrm{fed}^{-1}$. 


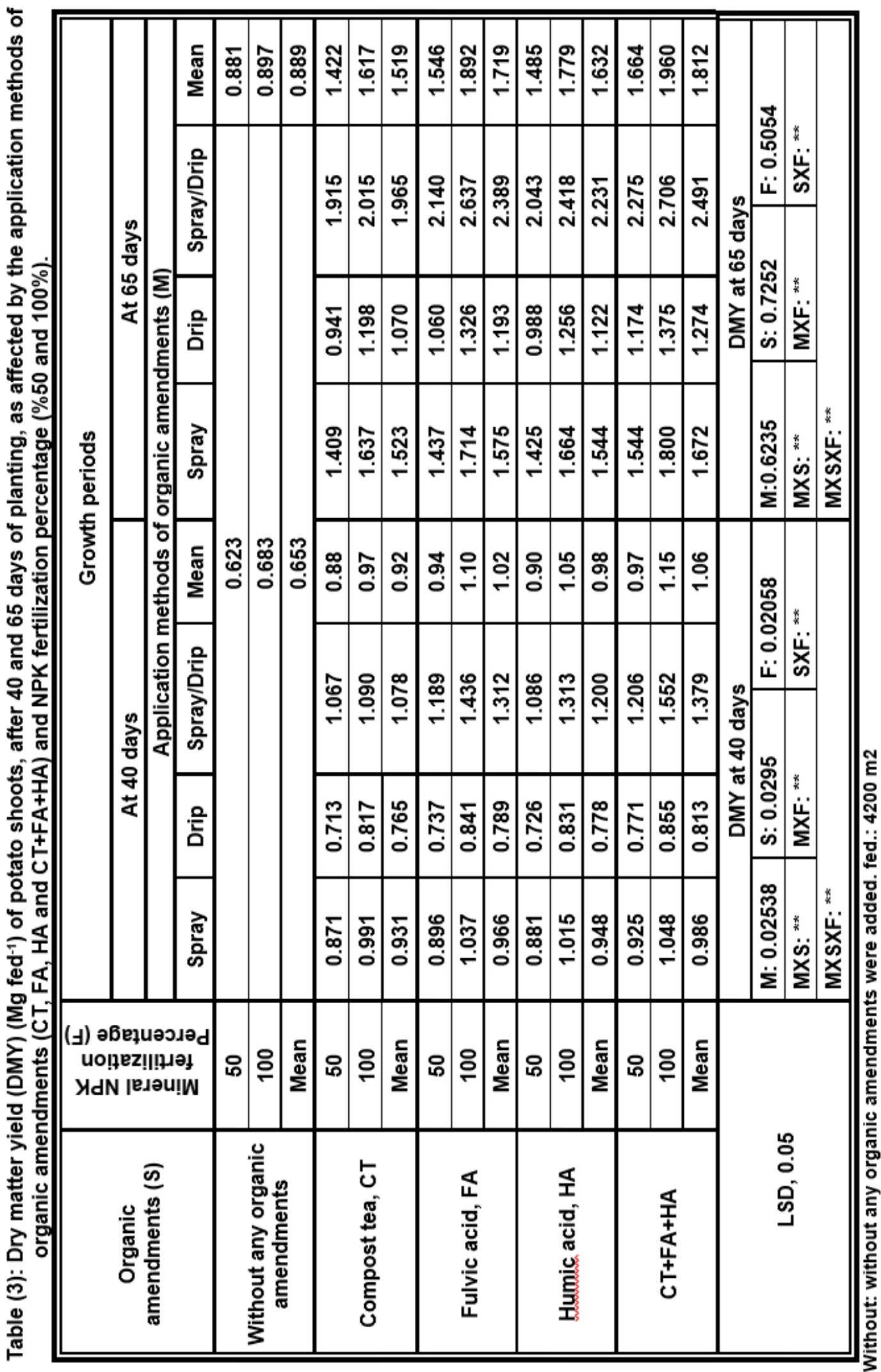




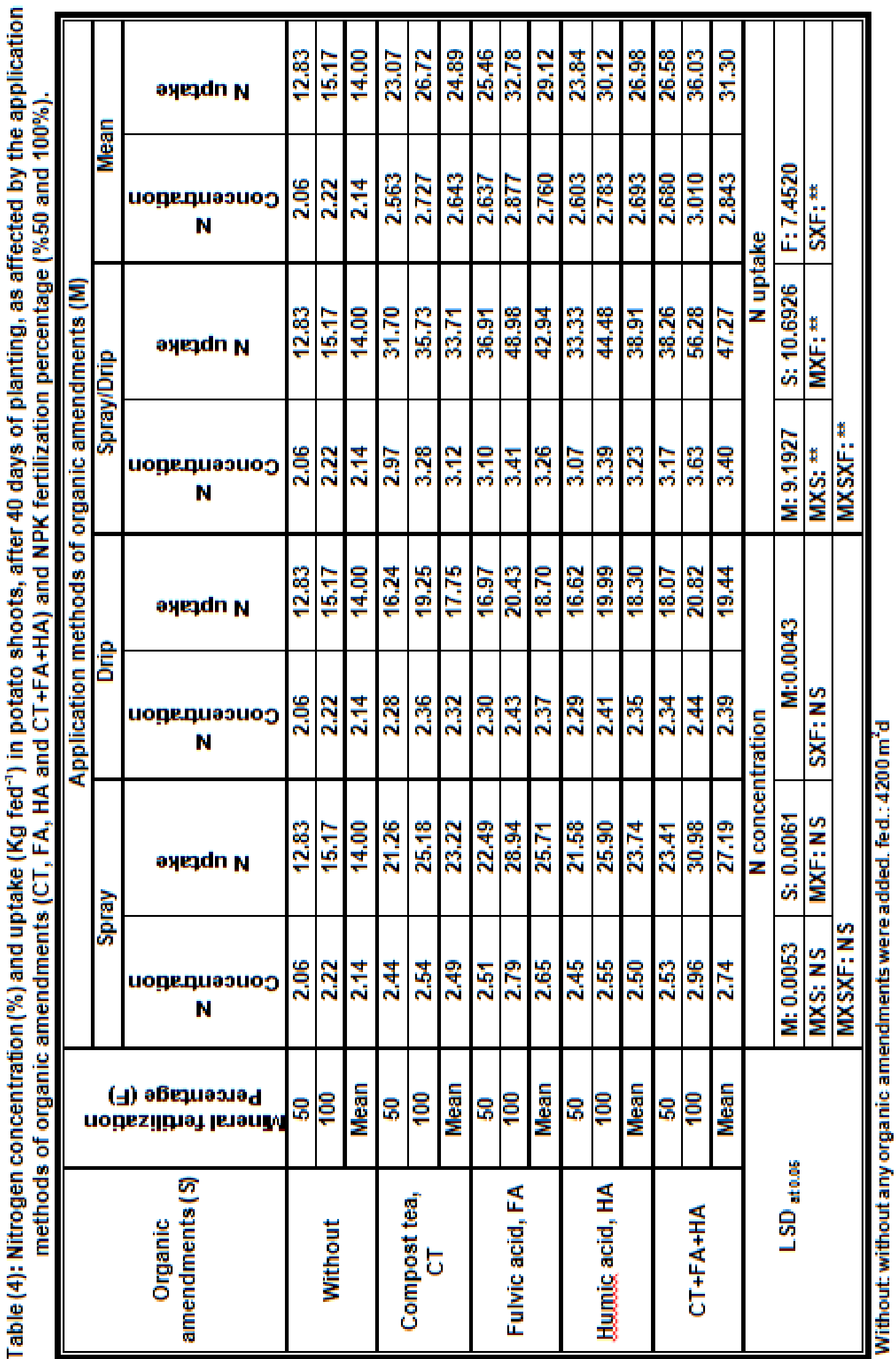




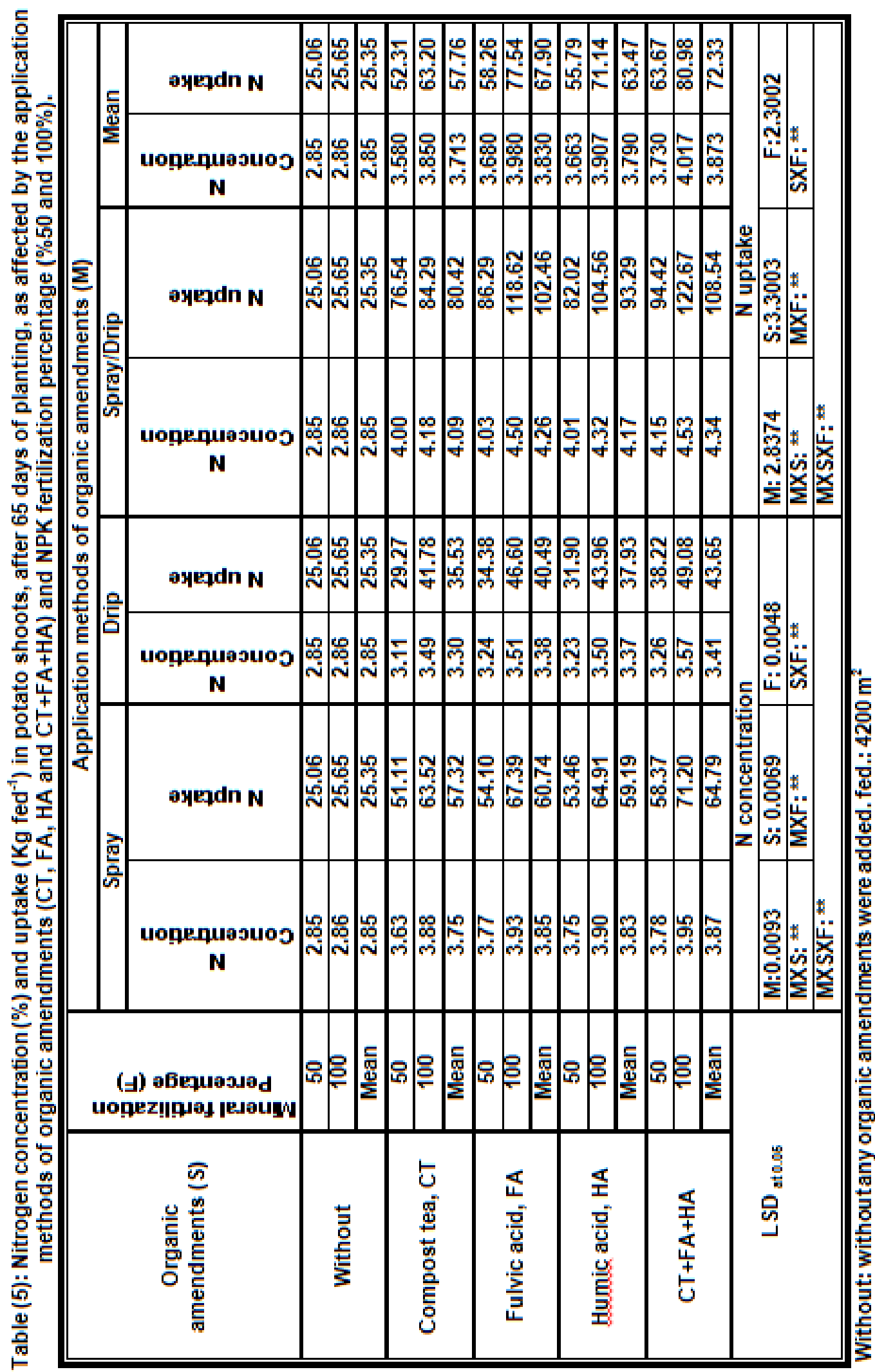




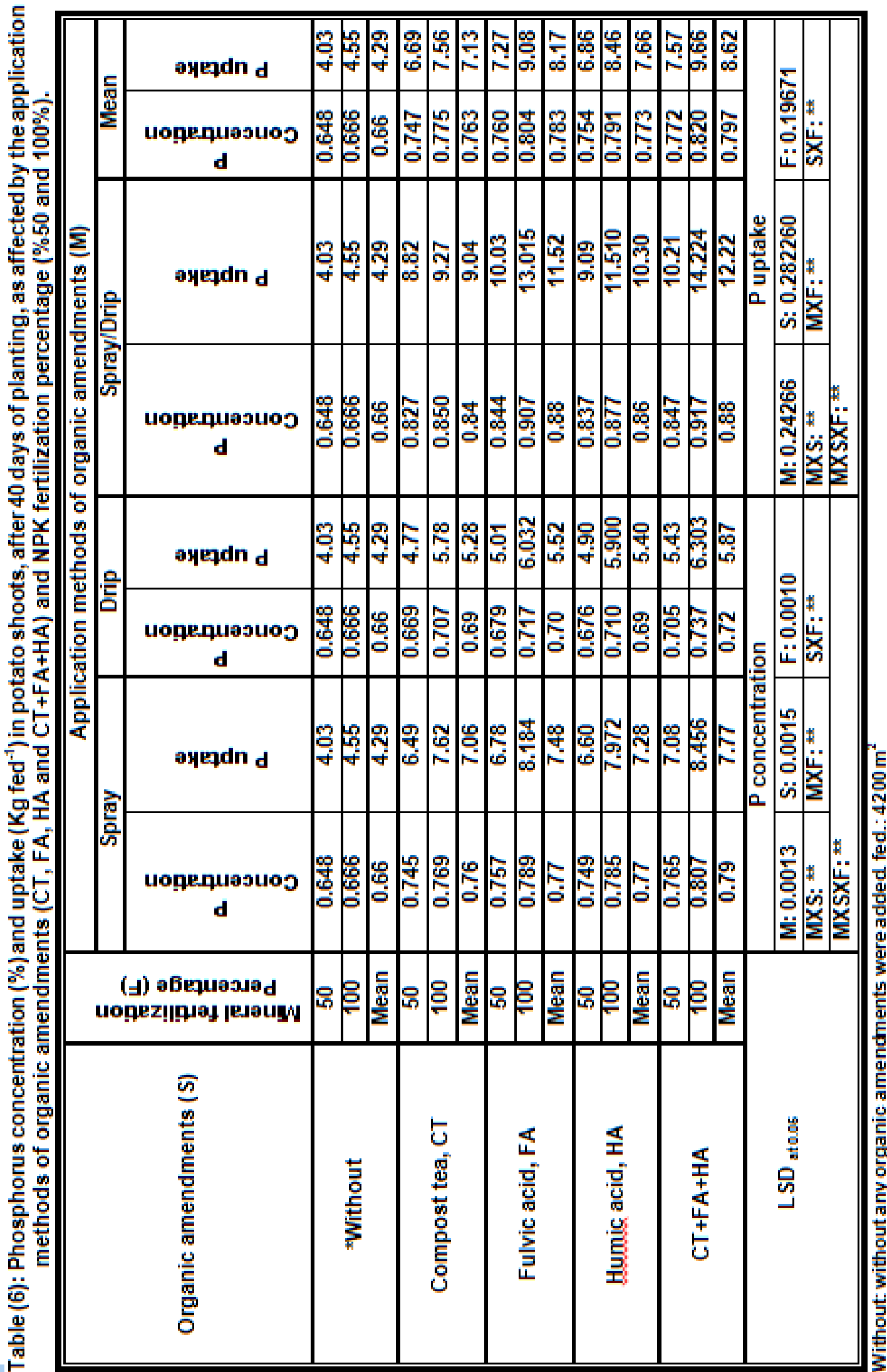




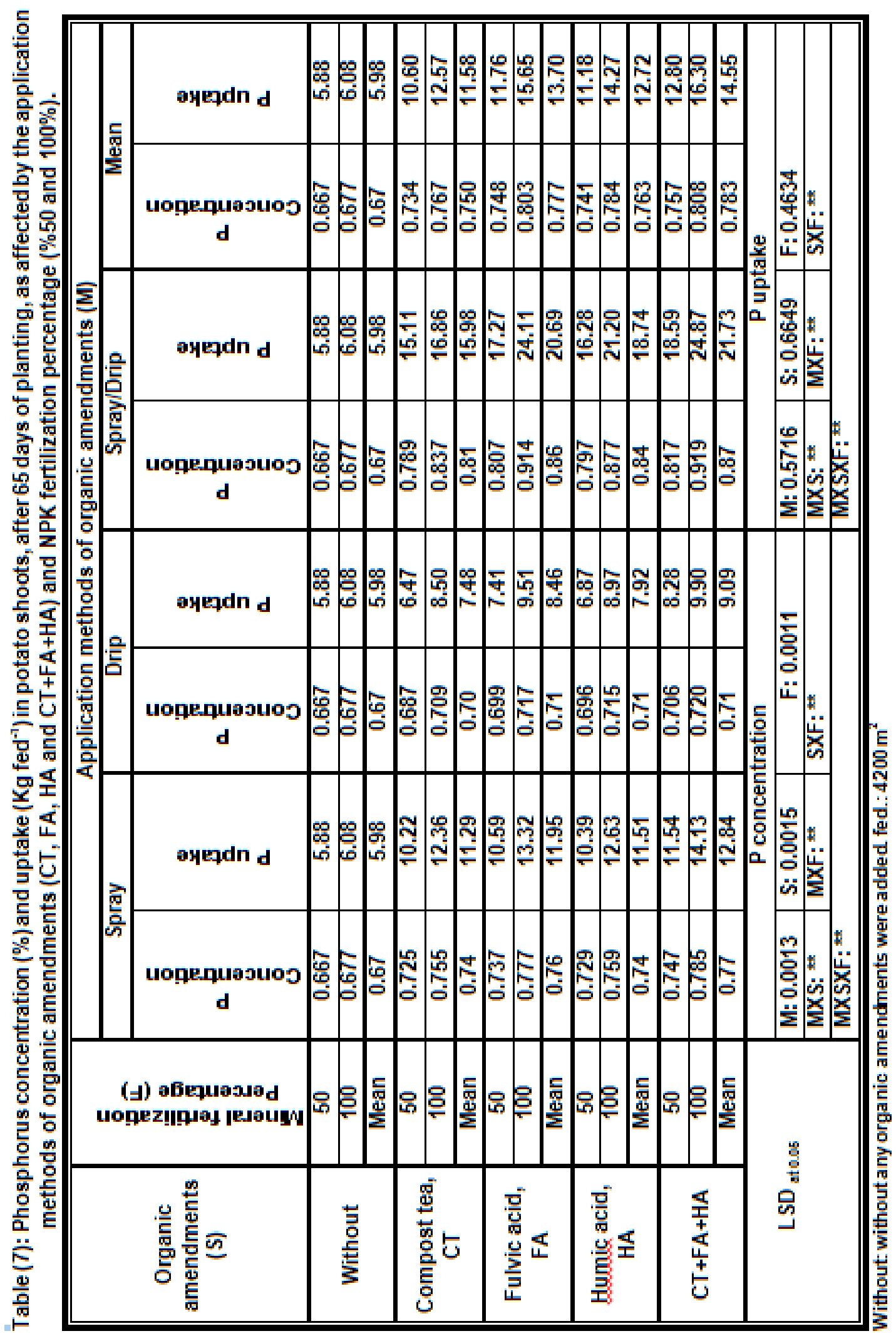




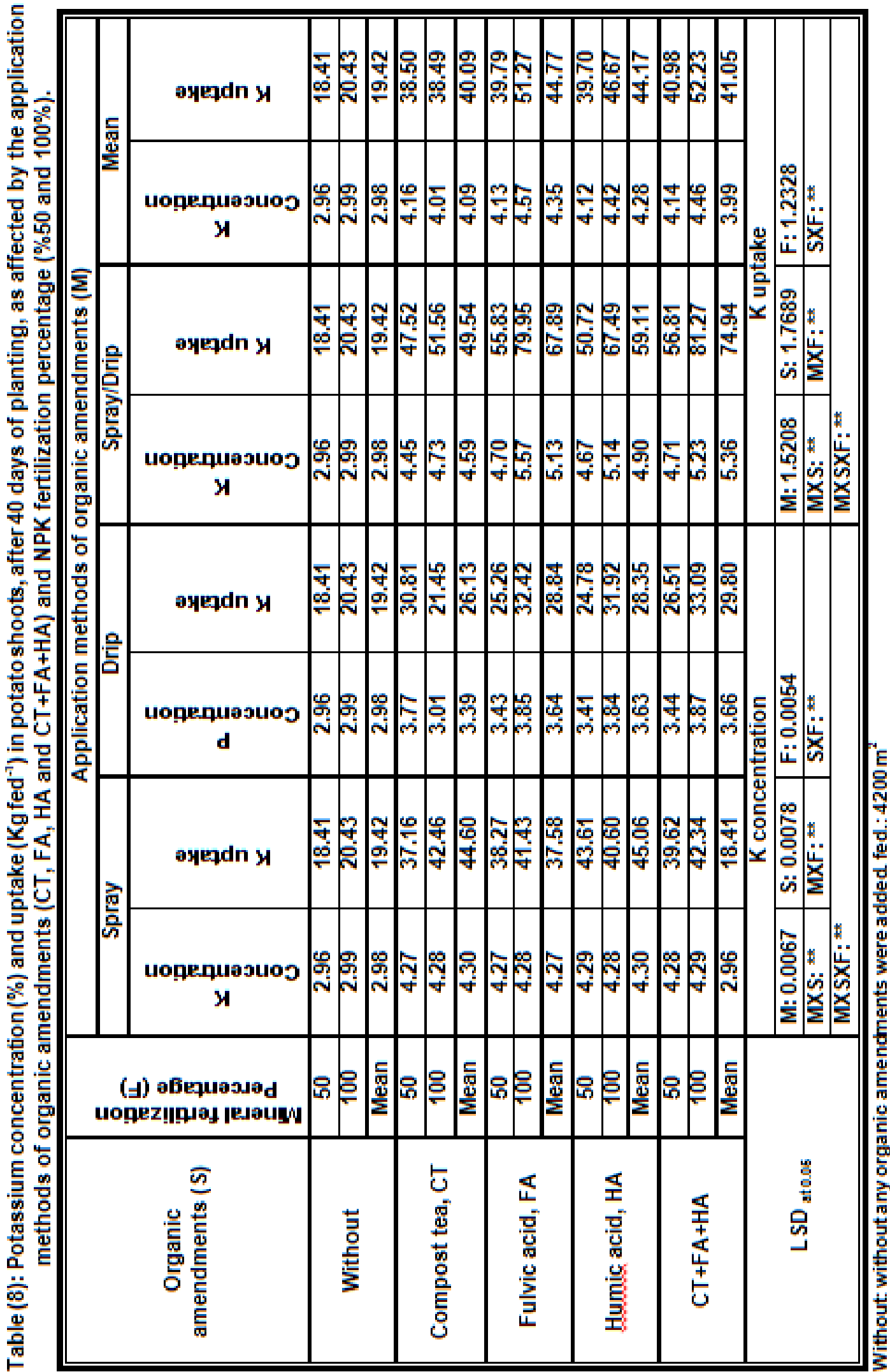




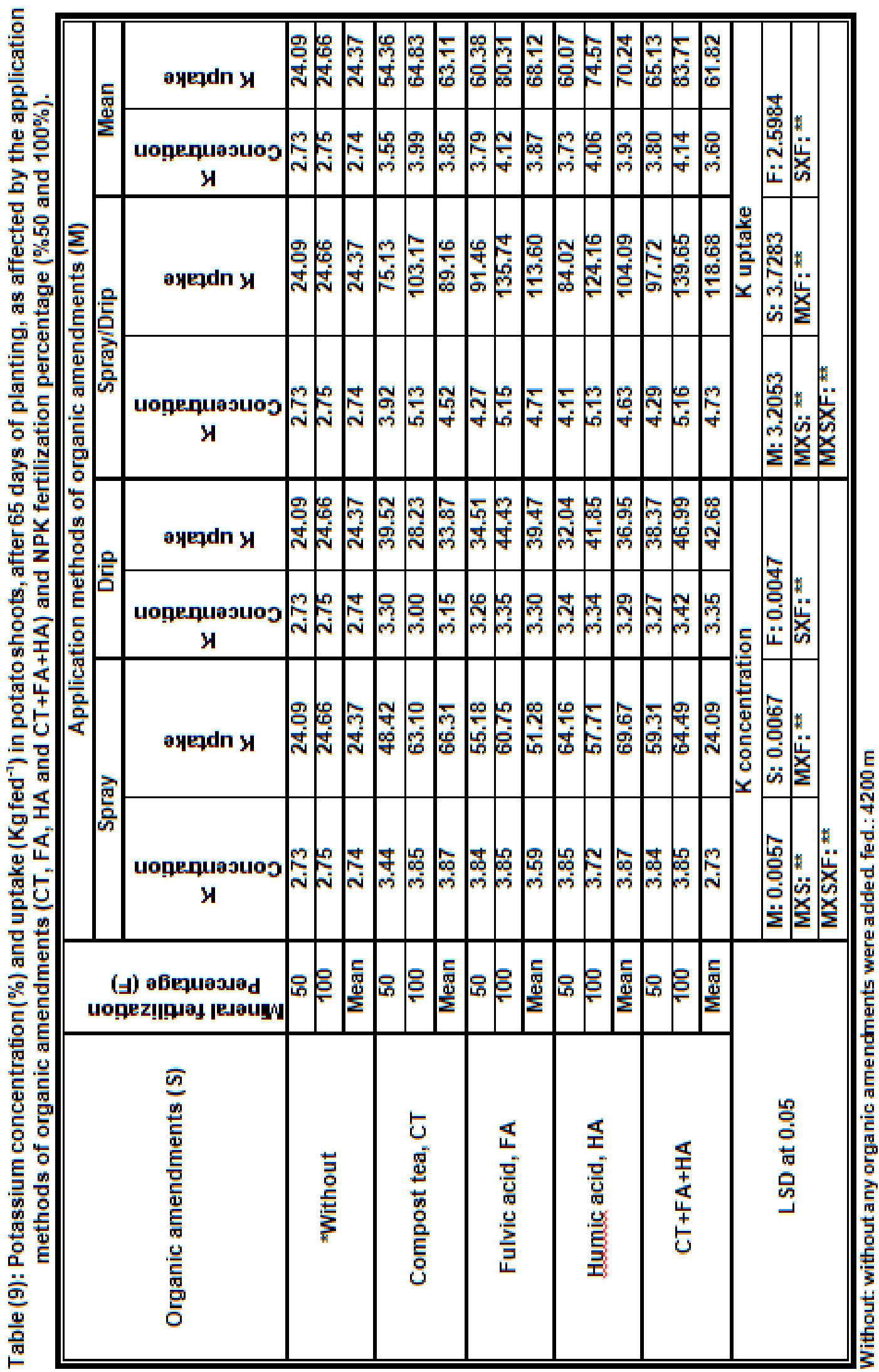




\section{b. Phosphorus (P) content}

Phosphorus content (\%) and uptake $\left(\mathrm{Kg} \mathrm{fed}^{-1}\right)$ of $P$ in potato shoots plants at 40 and 65 DAS are listed in Tables $(6$ and 7). These data demonstrated that, all application of organic amendments treatments in different methods significantly increased $P$ content in potato shoot plants. under two levels of RMFD, compared to the control (untreated) treatment. Under the highest levels $(100 \%)$ of the RMFD, the mixed application (Spray/Drip) method of CT, FA and HA of individually or in combination treatments appeared, a high $P$ content, in potato shoots plants. In regarding to mixed application (Spray/Drip) of CT, FA and HA in combination treatments led to a significant increases of $P\left(\mathrm{Kg} \mathrm{fed}{ }^{-1}\right)$ uptake in shoots.

The maximum values of $P$ content of shoots were obtained from the treatment of $100 \%$ of the RMFD in combination with duple application of CT, FA and HA, which recorded 0.917 and $0.919 \%$ which equal 14.22 and $24.87 \mathrm{Kg} \mathrm{fed}^{-1}$, at 40 and 65 DAS, respectively (Table, 6 and 7). Also, these data revealed that, the combined application of organic amendments adding mixed application methods "Spray/ Drip" under the highest level of mineral fertilization led to the maximum and significant increase of $P$ content. This may be in part due to compost tea fulvic and humic acids can interact with root organic acid exudates to increase the root area, primary root length, the number of lateral roots, and lateral root density (Canellas et al., 2008) and due to enhancing soil enzyme activity and promoting the growth and activity of microorganisms in the rhizosphere. Increased microbial numbers following compost tea (CT), fulvic and humic acids application is primarily due to the role of those organic amendments in creating soil conditions favor microbial replication (Sellamuthu and Govindaswamy, 2003). Indeed, foliar application of fulvic and humic acids increased photosynthetic and antioxidant metabolism (Fahramand et al., 2014). Moreover, the FA application in this study has positive effects on many important functions in plants including respiration, permeability of cell membranes، regulation of plant growth، root stimulation, nutrient uptake, cell division and elongation, seed germination and seedling development، chlorophyll synthesis and increase in crop yield (Quilty and Cattle, 2011).

\section{c. Potassium (K) content}

Tables (8 and 9) denote that, potato plants spraying or dripping with CT or FA or HA alone or in combination with RMFD (50 and 100\%) led to a significant increase in $K$ content of the plants compared to their control treatments. This combined application especially at $100 \%$ of the RMFD, gave a higher values of $\mathrm{K}$ concentration (\%) and uptake $(\mathrm{Kg}$ $\mathrm{fed}^{-1}$ ) in shoots which were $5.23 \%$ which equal $81.27 \mathrm{Kg} \mathrm{fed}^{-1}$ and were $5.16 \%$ which equal $139.65 \mathrm{Kg} \mathrm{fed}^{-1}$, at 40 and 65 DAS, respectively.

As an outlook at the results of dry matter yield (DMY) and in the NPK content in shoots of potato plants are appeared a high values with the double application methods (Spray/Drip) compared with these observed with the other application methods. These findings are due to interactions of HS with plant membrane transporters responsible for nutrient uptake and membrane associated signal transduction cascades which regulate growth and development (Canellas et al., 2015a). 


\section{Tuber yields $\left(\mathrm{Mg} \mathrm{fed}^{-1}\right)$ of potato plants.}

Data in Table (10) denote that tuber yield $\left(\mathrm{Mg} \mathrm{fed}^{-1}\right)$ was significantly affected by the studied treatments compared to their untreated control treatments. The potato plants which received the combined application of CT, FA and HA with $100 \%$ of RMFD, under different application methods of "Spray", "Drip" and the duple application (Spray/Drip) methods, gave the higher yields 22.34, 20.53, 23,80 $\mathrm{Mg} \mathrm{fed}^{-1}$, respectively. In the other hand, the maximum potato tuber yield was obtained with the incombination treatments of organic amendments applicated by the duple application methods "Spray/Drip": 21.65 and $33.80 \mathrm{Mg} \mathrm{fed}^{-1}$ under both levels of $\mathbf{5 0}$ and $100 \%$ of RMFD treatments, respectively. The application of the highest dose (100\%) of mineral fertilization gave significantly highly potato yield compared to the low (50\%) of mineral fertilization, under all studied application methods. These results are in similar with those reported by Kumar et al. (2007), who indicated that tuber yield of potatoes plant was increased by increasing of $\mathbf{N}$ application rates. The application of highest dose $(100 \%)$ of mineral fertilization gave significantly highly potato yield compared to the low $(50 \%)$ of mineral fertilization, under all studied treatments. These results are similar to those reported by Kumar et al. (2007), who indicated that tuber yield of potatoes plant was increased by increasing of the $\mathbf{N}$ application rates. Mahmoud and Hafez (2010) reported that, vegetative growth, yield and tuber quality as well as the tuber nutritive value of potato significantly increased with humic acid level increase. Tuber yield increased by $16.47 \%$ after addition of humic substances compared to the recommended rate solely. Soil application of humic acid significantly increased plant growth, total and marketable yield and tuber root quality (El-Sayed Hameda et al., 2011).

\section{Potato tuber macronutrients content}

Data in Tables (11 to 13) display that, spray or drip or spray/drip application methods of the organic either of alone or in combination (CT, FA and HA) to sandy soil with the two levels of mineral fertilization addition, generally enhanced in both concentration (\%) and uptake ( $\mathrm{Kg}$ $\mathrm{fed}^{-1}$ ) of NPK at harvest compared to the un-amended control treatments.

\subsection{Nitrogen ( $\mathrm{N}$ ) content}

Data in Table (11) denoted that, clear relation obtained by the application methods of organic amendments and both $\mathbf{N}$ concentration and its uptake by potato tuber. Higher contents of $\mathbf{N}$ were observed in the plants amended by FA treatments compared to the other individually organic amendments under all application methods. Individually applications of FA followed by HA were associated with the high $\mathbf{N}$ content compared with individual application of CT. The application methods of the organic amendments, the application methods of Spray/Drip was the uppermost treatment and followed by the spraying method. The maximum $\mathbf{N}$ concentration (\%) and tuber uptake (Kg fed $^{-1}$ ), were obtained with the incombination treat ments of organic amendments (CT+FA+HA), under the higher level (100\%) of mineral fertilization treatments, where concentration were $1.31,1.51$ and $1.79 \%$ which equal to 269.43, 337.28 and $424.17 \mathrm{Kg} \mathrm{fed}^{-1}$ with the "Drip", "Spray" and "Spray/Drip" application methods, respectively. These results are in line with the obtained by Shunka et al. (2017) and Korshunov et al. (2019) who reported that, the application of $\mathbf{N}$ fertilizers led to an increase in potato tuber yield and tuber $\mathbf{N}$ content. 
Evaluation effect of application methods of different sources of humic ........

Table 10 
Table 11 
Evaluation effect of application methods of different sources of humic ........

Table12 
Table 13 


\subsection{Phosphorus $(P)$ content}

Concerning the influence of application methods of organic amendments with the mineral fertilization on $P$ concentrations (\%) and tuber uptake $\left(\mathrm{Kg} \mathrm{fed}^{-1}\right)$ in Table (12).

Data proved that all application methods of the organic amendments significantly increased the tuber phosphorus content in compared to the unamended control treatment. The specific effect of both application method and organic amendments sources on $P$ content of tuber showed consistency with those mentioned before that at growth period of 40 and 65 DAS. According to the effect of organic amendments on $P$ content of potato tuber, the order was as follow: FA+ HA+ CT > FA > HA > CT. While the sequences for application methods effect arranged as: "Spray/Drip" > "Spray" > "Drip".

\subsection{Potassium (K) content}

Table (13) denote that, individual and combined application of organic amendments of (CT, FA and HA) led to a significant increase in $K$ content in the potato tuber with all studied treatments of its application methods under both mineral fertilization at levels (50 and $100 \%$ ) in compared to unamened control treatments. The combination treatments of the organic amendments. with the duple application methods "Spray/Drip" led to the maximum and significantly augmented $\mathrm{K}$ concentrations (\%) and tuber uptake $\left(\mathrm{Kg} \mathrm{fed}^{-1}\right)$ of potato plants. The plants received FA individually by "Drip", "Spray" and "Spray/Drip" application methods, in combination with the $100 \%$ of mineral NPK gave a higher values of $K$ uptake 405.12, 499.74 and $687.79 \mathrm{Kg} \mathrm{fed}^{-1}$, respectively, of $\mathrm{K}$ uptake in the potato tuber in compared to the individually application of HA or CT, with the same abovementioned application methods and the same level of RMFD.
The same aforesaid application methods of the in- combination treatments (CT+FA+HA) of the organic amendments with $100 \%$ of RMFD gave K uptake of 417.45509 .07 and $740.55 \mathrm{Kg} \mathrm{fed}^{-1}$, respectively.

The obtained results in Tables ( 3 to 13) attracted the attention to the importance of fulvic and humic acids and compost tea applied in particular by duple application methods (Spray/Drip) to enhance the plants dry weights which may be due to its positive effect on the availability of nutrients and on the growth, yield and quality of potato plants, consequently its beneficial effect on promoting the dry weight of the potato plants (De Corato, 2020). These findings confirm with those carried out by Yaxin, et al. (2019). It is worthy to mention that compost tea (CT) contains many of microorganisms that able to IAA production, nitrogenase activity and solubilization $P$. The application of compost tea with humic substances (FA and $H A$ ) lead to an increase in production of hormones, stimulating plant growth; one proposed mechanism to explain the benefits of compost application (Arancon et al., 2008). The application of compost tea was also useful for enhancing the growth of potato plants. Also, microorganisms produced the highest dry matter yields of potato plants, as well as the uptake of macronutrients. This could be referred to local changes in root morphology and biomass, i.e. larger numbers of tips extending surface within the rhizosphere and augmentation of the polysaccharide enrichment of the treated plants, when compared with the untreated controls (EI Zemrany et al., 2015 and 2019). Compost tea applied to plants alters their microbial populations by supplying exogenous microbes present in the tea, but also by supplying nutrients to support the growth and survival of endogenous microorganisms in the phyllosphere and rhizosphere. 
Such microbes can inhibit the growth of plant pathogens by various mechanisms, including the secretion of siderophores that bind iron, making it unavailable to the pathogen for normal growth and function (Stewart-Wade, 2020).

Also, the results in the present study revealed that, individually application of FA were mor efficient to promote the potato plants growth and macronutrient uptake by shoots and tubers than individual amended of HA or CT, under all studied treatments (Tables, 3 to 13). Results in this study revealed that, the maximum values of DMY and $N, P$ and $K$ contents of potato shoot and in tubers were obtained from in-combination treatments of organic amendments that applied by double application (Spraying/Drip method under both levels of RMFD (50 and 100\%).

\section{REFERENCES}

Anjun, SA., L. Wang, M. Farooq, L. Xue and S. Ali (2011). Fulvic acid application improves the maize performance under well-watered and drought conditions. J. Agron. Crop Sci., 197: 409-417. doi:10.1111/j.1439037X.2011.00483.X.

Arancon, N.Q., C.A. Edwards, A. Babenko, J. Cannon, P. Galvis and J.D. Metzger (2008). Influences of vermicomposts, produced by earthworms and microorganisms from cattle manure, food waste and paper waste, on the germination, growth and flowering of petunias in the greenhouse. Appl. Soil Ecol. 39: 91-99.

Bettoni, M. M., Á. F. Mogor, V. Pauletti, N. Goicoechea, I. Aranjuelo and I. Garmendia (2016). Nutritional quality and yield of onion as affected by different application methods and doses of humic substances. J. Food Compos. Anal., 51: 37-44. doi: 10.1016/j.jfca.2016.06.008
Bezuglova, O. S., A. V. Gorovtsov, E. A. Polienko, V. E. Zinchenko, A. V. Grinko and V. A. Lykhman (2019). Effect of humic preparation on winter wheat productivity and rhizosphere microbial community under herbicideinduced stress. J. Soils Sediments. 19: 2665-2675. doi:10.1007/ s11368018-02240-z.

Calvo, P., L. Nelson and J. W. Kloepper (2014). Agricultural uses of plant biostimulants. Plant Soil, 383: 3-41. doi:10.1007/s11104-014-2131-2138

Canellas, L.P., L.R.L. Teixeira, L.B. Dobbss, C.A. Silva, L.O. Medici, D.B. Zandonadi and A.R. Fraçana (2008). Humic acids cross interactions with root and organic acids. Ann. Appl. Biol., 153: 157-166.

Canellas, LP., F.L. Olivares, N.O. Aguiara, DL. Jones, A. Nebbioso, P. Mazzei and A. Piccolo (2015a). Humic and fulvic acids as biostimulants in horticulture. Sci. Hortic., 30: 15-27. doi:10.1016/j.scienta.2015.09.013.

Clair, S.B. and J.P. Lynch (2010). The opening of Pandora's Box: Climate change impacts on soil fertility and crop nutrition in developing countries. Plant Soil, 335: 101-115.

Cottenie, A., M. Verloo, L. Kiekens, G. Velghe and R. Amertynck (1982). Chemical Analysis of Plants and Soils. Laboratory of Analytical and Agrochemistry State University, Ghent, Belgium., pp.50-70. Curtin, L.V..

Da Silva, S. F., F. L. Olivares and L. P. Canellas (2017). The biostimulant manufactured using diazotrophic endophytic bacteria and humates is effective to increase sugarcane yield. Chem. Biol. Technol. Agric., 4: 24. doi: 10.1186/ s40538-017-0106-108

De Corato, U. (2020a). Agricultural waste recycling in horticultural intensive farming systems by on-farm 
composting and compost-based tea application improves soil quality and plant health: A review under the perspective of a circular economy. Science of the Total Environment, 738: 139840.

https://doi.org/10.1016/j.scitotenv.2020 .139840

Dionne, A., R.J. Tweddell, H. Antoun and T.J. Avis (2012). Effect of non-aerated compost teas on damping-off pathogens of tomato. Can. J. Plant Pathol. 34 (1): 51-57. https://doi. org/10.1080/07060661.2012.660195

Dragunova, A.F. (1958). A rapid method for determining functional groups in humic acids. Nauch. Trydy. Mosk. In Zh.-ekonon. Inst. Ser. Khim. Proizvod., (10) (C.F. Kononova, 1966).

Ekin, Z. (2019). Integrated use of humic acid and plant growth promoting rhizobacteria to ensure higher potato productivity in sustainable agriculture. Sustainability, 11: 3417. doi: 10.3390/su11123417.

El Zemrany, H. M., G. A. A. Mekhemar and S. S. Abd EI Salam (2019). Evaluation efficiency of liquid Bradyrhizobium and Azotobacter chroococcum DSM 2286 as co-inoculation affected by salinity level of irrigation water on peanut in sandy soils of Egypt. Menoufia J. Soil Science, 4: 201-217.

El Zemrany, HM., MM. El-Shinnawi, EA. Abou Husssien and BA. Abdel-Whab (2015). Evaluation of certain local bacterial strains as diazotrophs for wheat plants. Minufiya J. Agric. Res., 40 (2): 263-278.

Eleiwa, M.E., S.A. Ibrahim and M.F. Mohamed (2012). Combined effect of NPK levels and foliar nutritional compounds on growth and yield parameters of potato plants (Solanum tuberosum L.). African J. Microb. Res., 6: 51005109-.
El-Sayed Hameda, E.A., A. Saif EI Dean, S. Ezzat and A.H.A. El Morsy (2011). Responses of productivity and quality of sweet potato to phosphorus fertilizer rates and application methods of the humic acid. International Research Journal of Agriculture Science and Soil Science, 1 (9): 383-393.

Fahramand, M., H. Moradi, M. Noori, A. Sobhkhizi, M. Adibian, S. Abdollahi and K. Rigi (2014). Influence of humic acid on increase yield of plants and soil properties. International J. of Farming and Allied Science, 3(3): 339341.

FAO. (2017). FAOSTAT. http://faostat.fao.org. Accessed October, 2018.

Gomez, K.A. and A.A. Gomez (1984). Statistical Procedures for Agricultural Research. 2nd ed., International Rice Research Institute, College, Laguna, 680pp.

Hanafy, A. H., H. F. Y. Mohamed, I. O. A. Orabi and A. M. El-Hefny (2018). Influence of gamma rays, humic acid and sodium nitroprusside on growth, chemical constituents and fruit quality of snap bean plants under different soil salinity levels. Biosci. Res., 15: 575-588.

Hernandez, A., Castillo, H., Ojeda, D., Arras, A., Lopez, J. and E. Sanchez, (2010). Effect of vermicompost and compost on lettuce production. Chilean J. Agric. Res., 70 (4): 583-589.

Ibrahim, H. A. K. (2019). Effect of foliar application of compost water extract, humic acid, EDTA and micronutrients on the growth of fenugreek plants under sandy soil condition. Int. J. Environ. Sci. Technol., 16: 7799-7804. doi:10.1007/s13762-019-02311-2319.

Ingham, E.R. (2005). The Compost Tea. Brewing Manual. 5th edition. Soil Food web, Incorporated, Corvallis, OR, US. 
Khaled, H. and H.A. Fawy (2011). Effect of different levels of humic acids on the nutrient content, plant growth, and soil properties under conditions of salinity. Soil Water Res., 6 (1): 21-29. https://doi.org/10.17221/4/2010-SWR.

Klute, A. (1986). Methods of Soil Analysis, Part 1: Physical and Mineralogical Properties. Amer. Soc. Agron. Inc. Madison, Wise., USA.

Kononove, M. M. (1966). Soil Organic Matter. 2nd ed. Pergamon Press, Oxford.

Korshunov, A., N. Gaitova, M. Gaitov, A. Cheremisin and A. Gerner (2019). Management methods of nitrate content in potato applicable to the soil-climate conditions of Russia. IOP Conf. Ser. Earth Environ. Sci., 390, 12009. https://doi.org/10.1088/ 17551315/390/1/012009.

Kumar, P., S.K. Pandy, B.P. Singh, S.V. Singh and D. Kumar (2007). Effect of nitrogen rate on growth yield economics and crisps quality of Indian potato processing cultivars. Potato Res., 50: 143-155. https://doi.org/ 10.1007/s11540-0089034-0.

Mahmoud, E.K., N. Abd EL-Kader, P. Robin, N. Corfini and L. Abd ElRahman (2009). Effects of different organic and inorganic fertilizers on cucumber yield and some soil properties. World J. Agric. Sci., 5 (4): 408-414.

Mahmoud, A.R. and M.M. Hafez (2010). Increasing productivity of potato plants (Solanum tuberosum, L) by using potassium fertilizer and humic acid application. International Journal of Academic Research, 2 (2):83-88.

Morard, P., Eyheraguibel, Morard B. and J. Silvestre (2011). Direct effects of humic-like substance on growth, water, and mineral nutrition of various species. J. Plant Nutr., 34 (1): 46-59. https://doi.org/10.1080/01904167 2011.531358.

Muleta, H. D. and M.C. Aga (2019). Role of Nitrogen on Potato Production: A Review. J. Plant Scie., 7(2): 36-42. doi: 10.11648/j.jps.20190702.11

Page, A.L., R. H. Miller and D.R. Keeny (Ed.) (1982). Methods of Soil Analysis, Part 2 Chemical and Microiological Properties. American Society of Agronomy Inc. Mascson, Wisconsin USA.

Palumbo, G., M. Schiavon, S. Nardi, A. Ertani, G. Celano and C.M. Colombo (2018). Biostimulant potential of humic acids extracted from an amendment obtained via combination of olivemill wastewaters (OMW) and a pre-treated organicmaterial derived from municipal solid waste (MSW). Front. Plant Sci., 1028. https://doi.org/10.3389/fpls.2018. 01028.

Quilty, J. and S. Cattle (2011). Use and understanding of organic amendments in Australian Agriculture: A Review. Soil Res., 49 (1): 1-26.

Selim, E. M. and A. A. Mosa (2012). Fertigation of humic substances improves yield and quality of broccoli and nutrient retention in a sandy soil. J. Plant Nutr. Soil Sci., 175: 273-281. doi: 10.1002/jpln.201100062.

Sellamuthu, K.M. and M. Govindaswamy (2003). Effect of fertilizer and humic acid on rhizosphere microorganisms and soil enzymes at an early stage of sugarcane growth. Sugar Technol., 5: 273-274.

Shunka, E., A. Chindi, G. Wgiorgis, E. Seid and L. Tessema (2017). Effect of nitrogen and potassium application rates on nitrogen use efficiency and tuber minerals content in central high lands of Ethiopia. J. Hortic. For., 9 (1): 
1-8.

https://

doi.org/10.5897/JHF2016.0467.

Stewart-Wade, S.M. (2020). Efficacy of organic amendments used in containerized plant production: Part 1. Compost-based amendments. Review. Scientia Horticulture, 266: 1-21. https://doi.org/10.1016/i. scienta.2019.108856,

Waqas, M., B. Ahmad, M. Arif, F. Munsif, A. Latif Khan and M. Amin (2014). Evaluation of humic acid application methods for yield and yield components of Mungbean. Am. J. Plant Sci., 5: 2269-2276. doi: 10.4236/ajps.2014.515241
Yaxin, X., H. Ping, X. Xinpeng, Q. Shaojun, U. Sami, G. Qiang and Z. Wei (2019). Estimating Nutrient Uptake Requirements for Potatoes Based on QUEFTS Analysis in China. Soil Ferti. and Crop Nutrition. J., 111: 1-8. doi:10.2134/agronj2018.09. 0572.

Zandonadi, D.B., C.B. Ribeiro Mato, R.N. Castro, R. Spaccini, Lopes Olivares, F. and L.P. Canellas (2019). Alkamides: a new class of plant growth regulators linked to humic acid bioactivity. Chem Biol Technol Agric., 6: 23. https://doi.org/10.1186/s40538-0190161-4. 
تقييم تأثير طرق إضافة مصادر مختلفة من المواد الابالية علي نمو وإنتاجية وجودة نبات البطاطس المنزرع في أرض رملية تحت مستويات مختلفة من الأسمدة المعدنية

$$
\begin{aligned}
& \text { بلر يوسف الكومي(1)، الحسيني عبد الغفار (بوحسين (1)، منال فتحي طنطاوي(2)، } \\
& \text { وإلهام المغاوري نور الدين السبد (1) } \\
& \text { (1) قسم علوم الأراضي ـ كلية الزراعة ـ جامعة المنوفية }
\end{aligned}
$$

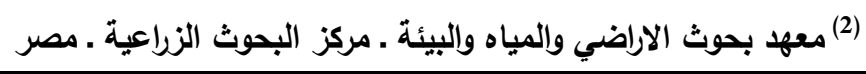

$$
\begin{aligned}
& \text { الملخص العربي }
\end{aligned}
$$

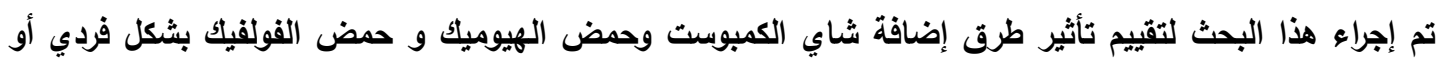

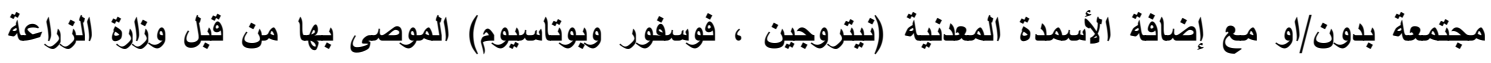

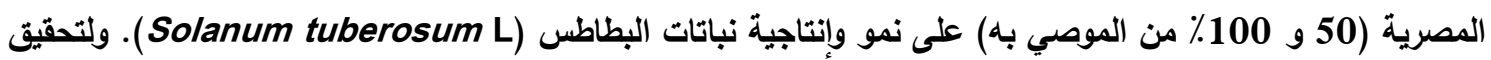

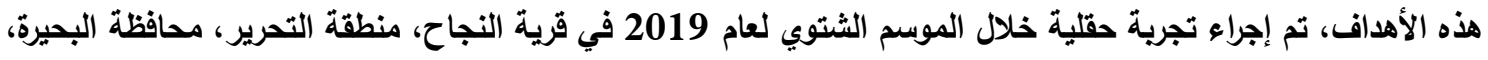

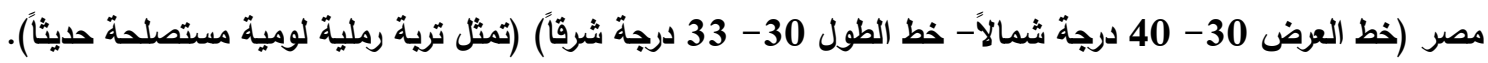

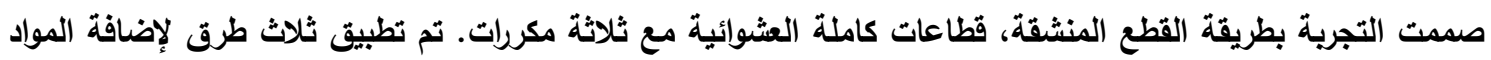

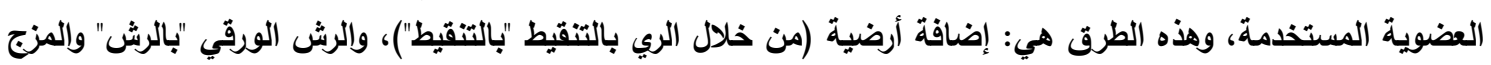

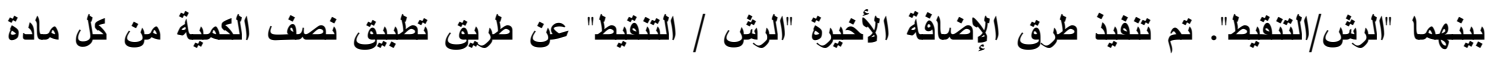

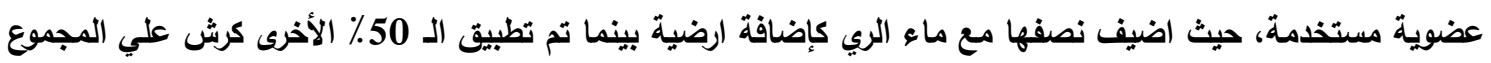

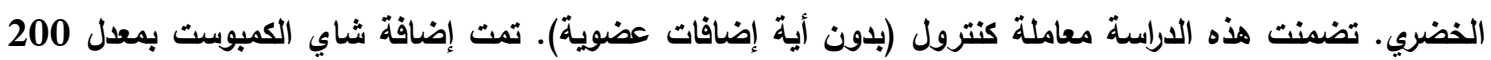

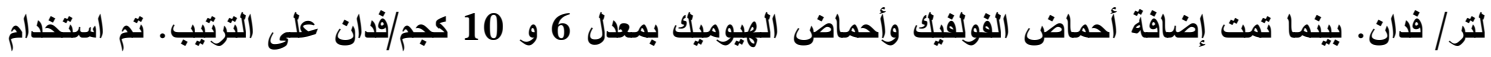

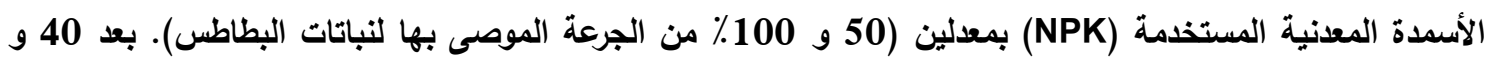

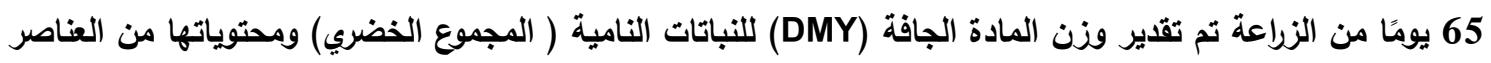

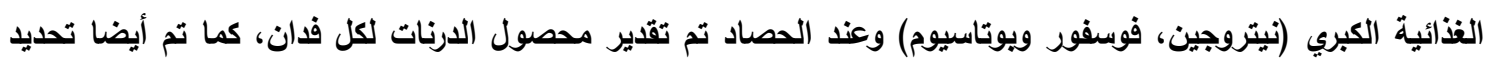

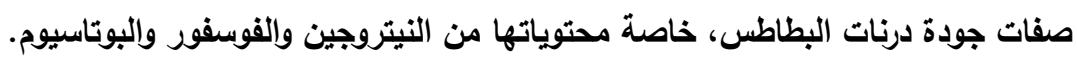

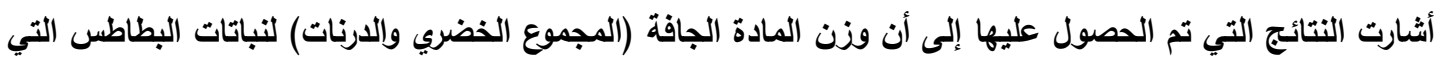

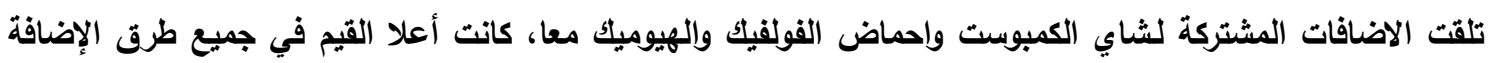

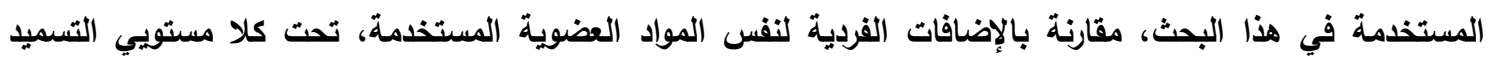

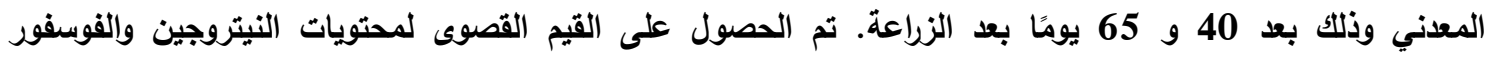

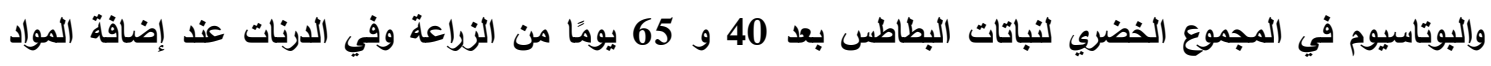

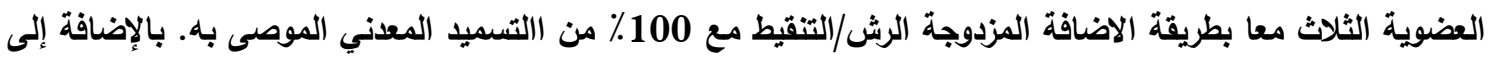

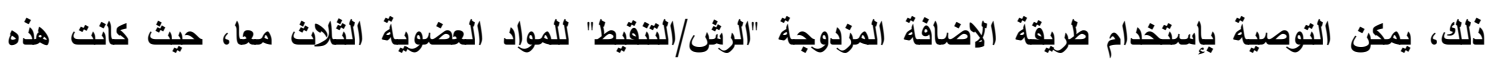

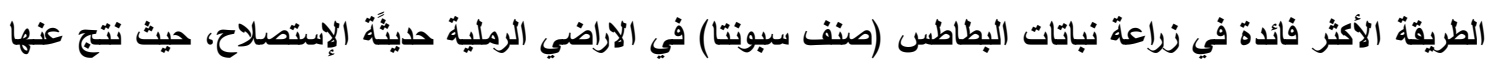

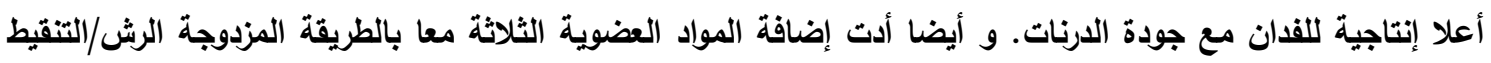

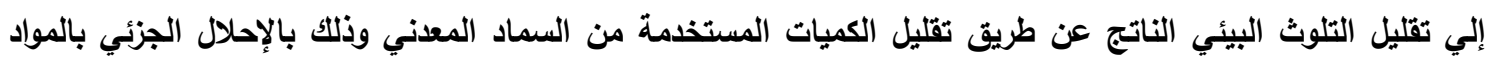

العضوية المضافة.

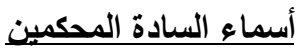
أ.د/ ناصر إبراهيم كمال عبدالقادر كلية الززاعة - جامعة طنطا ، أ.د/ محمد أبوالفضل أحمد لية الزراعة - جامعة المنوفية 
